\title{
THE HISTORY OF NEW ZEALAND LEGAL EDUCATION: A STUDY IN AMBIVALENCE
}

\author{
PETER SPILLER*
}

The profession has never seemed able to make up its mind about legal education. It wanted to establish itself as a liberal profession .... [but] at each stage it was necessary to convince a conservative body of men that changes in a familiar system were necessary. ${ }^{1}$

\section{INTRODUCTION}

The ambivalence which has characterised the history of legal education in England, as described in the above quote, has also been a persistent feature of legal education in New Zealand. This is not surprising in view of the heavy influence which English norms and traditions have exerted on the New Zealand profession. ${ }^{2}$ As in England, lawyers in New Zealand saw themselves as belonging to a cultured body of people with common skills and ideals. As part of this outlook, New Zealand lawyers came to accept, however grudgingly or hesitatingly, that they needed to know more than the mere mechanics of practice and that they needed to be exposed at least to the basics of other (academic) disciplines. ${ }^{3}$ At the same time, New Zealand lawyers inherited the English mindset that law, being an essentially applied discipline, was best learnt through selfhelp in the practice of the profession. New Zealand lawyers tenaciously clung to the English notion that immersion in practice was the only realistic way in which aspirant lawyers could learn to be effective operators of the rules and processes which regulated human conduct. This article will analyse the history of New Zealand legal education in the light of the continuing tension 
between the above two themes. It will do so in the context of four chronological periods which reflected important shifts in the goals and directions of New Zealand legal education.

\section{PRE-UNIVERSITY DEVELOPMENTS (1841-73)}

From the outset, the New Zealand profession was theoretically made up of two distinct branches, barristers and solicitors, with separate qualifications, even though the realities of a "sparsely settled new land" meant that lawyers were in fact allowed to practice as both barristers and solicitors. ${ }^{4}$ The founding ordinances and rules governing admission as barristers and solicitors in New Zealand were based almost entirely on the assumption that those who were admitted would have qualified elsewhere, particularly in the United Kingdom. ${ }^{5}$ The only concession to the admission of local barristers was a provision in the Supreme Court Ordinance of 1844 which allowed those who had qualified under any New Zealand prescription to be eligible for admission, but no prescriptive rules were in fact made prior to 1861. For locals who wished to be admitted as solicitors, the Supreme Court Ordinances of 1841 and 1844 provided that those who had served a clerkship with a solicitor could be admitted, and the Supreme Court Rules of 1844 specified the term of five years' articles of clerkship. But no provision was made for the examination of candidates before admission, and after the repeal of the 1844 Rules (in 1856) there were no Rules governing admission of local candidates. ${ }^{6}$ The absence of a structure for local legal education and training was not surprising in view of the current state of legal education in the United Kingdom. In 1846 a Select Committee of the House of Commons, appointed to examine legal education in England and Ireland, reported that the student was "left almost entirely to his own individual exertions, industry and opportunities and that no Legal Education worthy of the name of a public nature is to be had. $^{7}$

However, by the late 1850s, pressure grew for the development of rules governing local qualification for admission to the profession. By this stage there were lawyers (such as future Supreme Court judge Thomas Gillies) who had qualified for admission on the basis of service in local legal firms, and there was the need to make better provision for them. Further, steps were 
being taken in England to address the problems identified by the 1846 Report, and these culminated in the Solicitors Act 1860 which authorised a preliminary examination ("to show that the would-be entrant had a sound general education”) and an intermediate examination in the general principles of law. ${ }^{8}$ In 1859 the New Zealand judges issued a report on qualification for and admission to the profession, and this commented on the defective state of the law on local qualification and stressed the need for reforms along English lines, including formal examinations for candidates to the profession. $^{9}$

The judges' recommendations were developed and enacted in the Law Practitioners Act 1861. In terms of this Act, the judges of the Supreme Court were empowered to regulate the qualification and examination of those wishing to qualify for admission as barristers and as solicitors ${ }^{10}$ The judges' rules, which were promulgated in 1864, duly framed two types of examinations for barristers and for solicitors. First, for barristers and for solicitors who had not been admitted overseas and for local barristers who did not have a degree in arts or law, there was an examination in general knowledge. Both the barristers' and solicitors' examinations were along the lines of the examinations recommended by the English Report of 1846, and Ancient and Modern History, the Feudal System, the British Constitution, Etymology, Latin and Algebra. ${ }^{11}$ Secondly, for all candidates there was an examination in law, which, for those admitted overseas, was an examination specifically in New Zealand law so far as it differed from English law. ${ }^{12}$ The examinations were conducted by the judge for the district concerned, assisted by a practitioner and a "literate person", they were in written and oral from, and "much greater proficiency" was expected of barristers (as opposed to solicitors) in the comprehensiveness of their knowledge. ${ }^{13}$ Admission of local candidates as solicitors also required a period of articles: this remained a requirement until 1882, when the "advanced democratic view [that] no obstacles be placed in the way of any citizen who wished to become a lawyer” prevailed. ${ }^{14}$

Thus, the formal structure of local qualification had been created in New Zealand. The Act of 1861 was of long-term significance in at least two respects. First, the preliminary examination signalled the acceptance of the need for legal 
education to proceed against the background of an acceptable (nonlegal) general education. Secondly, the powers of examination vested in the hands of the judges meant that the New Zealand legal profession (as distinct from other professions such as medicine and engineering) inherited the English tradition of vesting the responsibility for its education in those engaged in the administration of justice. ${ }^{15}$ However, while the structure of legal education had been created, there was no immediate provision made for actual training and supervision. In the absence of law teaching institutions, students had "no means of qualifying themselves for their profession beyond the aid with which books can supply them". ${ }^{16}$ Further, both the general examination and the law examination were notoriously easy, superficial and dependent on rote learning ability. ${ }^{17}$ Again, these features mirrored the position of legal education in England. ${ }^{18}$ All this facilitated the growth of university involvement in the education of lawyers, which took place from the 1870 s onwards.

\section{EARLY DEVELOPMENT OF UNIVERSITY LEGAL EDUCATION (1870s TO 1920s)}

In 1870 the University of New Zealand was created, and by the mid-1870s law students were allowed to take university arts courses in place of the general knowledge examination and limited law classes commenced at Otago University and Canterbury University College. ${ }^{19}$ In 1877 the University of New Zealand established the LLB degree and by 1888 the degree covered all the law subjects specified in the Rules for admission of barristers. ${ }^{20}$ In 1889 the judges issued new Rules which delegated to the University of New Zealand their statutory responsibility for examining candidates for admission. ${ }^{21}$ For barristers, the judges' Rules prescribed a credit pass in junior scholarship or a pass in the first (non-law) section of the LLB degree as the general knowledge examination, and the LLB law subjects as the law curriculum. For solicitors, a pass in matriculation was sufficient for the general knowledge requirement, and the law professional examinations covered the LLB law subjects less Jurisprudence, Constitutional History, Roman Law, International Law and Conflict of Laws. ${ }^{22}$ Until the 1920s, it remained the norm for New Zealand lawyers to 
qualify on the basis of the solicitors' law professional examinations rather than the LLB degree, as solicitors retained the right to practise as both solicitors and barristers. This tendency was accentuated after 1898 when the Law Practitioners Amendment Act introduced the "back door principle" whereby a solicitor could be admitted as a barrister after five years' practice, without passing the barristers' examinations. $^{23}$

The teaching of law at the university level began in Otago, the most prosperous and populous of the New Zealand settlements in the late 1860s. ${ }^{24}$ In 1869 the Otago Provincial Council passed the University of Otago Ordinance establishing a university as a corporate body with power to grant degrees in arts, medicine, law and music. $^{25}$ A select committee appointed by the Provincial Council strongly recommended the institution of law classes in view of the educational needs of law candidates in Dunedin. ${ }^{26}$ As a result, in April 1873, Robert Stout was appointed (part-time) lecturer in common law, including law of contracts, to give two lectures per week, at a salary of $£ 50$ with class fees of three guineas per student. ${ }^{27}$ In 1876 Stout was succeeded by Frederick Chapman, who was in turn succeeded in 1878 by Allan Holmes, during whose tenure the Jurisprudence course became "practically and primarily the only course". ${ }^{28}$ During the 1880 s Constitutional History and Law was also taught, not by a local lawyer, but by the Otago University Professor of English and Political Economy. As the District Law Society recognised, "economic considerations at present stand in the way of establishing a school of law with any pretence to completeness". ${ }^{29}$ In 1890, in terms of an arrangement with the District Law Society (whereby the Society retained the examination fees and supported the lecturers), two part-time lecturers were appointed from the local profession to teach Constitutional History and the Law of Property, alongside the teaching of Jurisprudence. By 1893 the law staff was reduced to two, who taught the subjects Constitutional History and Jurisprudence, and this continued the position until 1908 (except for the period 1902-05, when the retrenchment of staff saw the temporary disappearance of law teaching altogether). ${ }^{30}$ In 1908, on the request of the Law Students' Society that arrangements be made for professional teaching in all subjects required for the LLB, James Garrow was appointed full-time lecturer in law, but his 
appointment as professor of law at Victoria in 1910 brought the teaching of professional law subjects to an end. The following year a deputation representing the Law Society complained to the University Council that "although the Otago University had now been established for more than 30 years, there was not the same teaching in Law that there had been two years after its foundation". ${ }^{31}$ The Law Society and the Council agreed to a scheme whereby the Society would contribute $£ 100$ per annum and the University a further $£ 50$ to the cost of professional instruction. In 1912 a panel of six lecturers was appointed to teach law professional courses, and the following year the Faculty of Law was established. ${ }^{32}$ The end of World War I brought a considerable improvement in student numbers, and in 1919 the University took over the full financial burden of the teaching of law, supporting seven law teachers. ${ }^{33}$ Despite these improvements, the provision of law teaching at Otago University by the 1920s was still at a limited level. All the staff were part-time, as were the students (except in their first year), and the library and lectures were in the Supreme Court building. ${ }^{34}$

Further, there was considerable dissatisfaction with the overall system of legal education. In 1923 the Otago District Law Society Council called for a longer professional course (to ensure greater maturity on completion), a tougher general knowledge examination for solicitors, and professional examinations which tested the "grasp of principles and the capacity to apply them" rather than "merely memorised knowledge". 35

In 1872 the Canterbury Collegiate Union was established and this subsequently became Canterbury University College, affiliated to the University of New Zealand. In 1874 Charles James Foster, former professor of Jurisprudence at University College, London, was appointed lecturer in Jurisprudence. ${ }^{36}$ However, response to Foster's teaching of law was poor, as practitioners complained that their law clerks were being taught in too academic a way. The result was that students opted to complete their courses mainly by private study, and at the beginning of 1880 lectures were discontinued. ${ }^{37}$ Three years later classes were resumed by William Izard, whose lectures were "sound, delivered in a pleasant, informal and chatty manner", who helped "to develop habits of steady reading”, but who ultimately found that "his work as a lecturer 
occupied so much time that his bridge suffered". ${ }^{38} \mathrm{He}$ was succeeded in 1902 by G T Weston, who recalled that each week he taught Jurisprudence and delivered seven other lectures covering Roman law, International law, Conflict of Laws and the entire law professional curriculum, with the aid of an inadequate library and almost no New Zealand textbooks. ${ }^{39}$ Classes remained small as many students continued to complete their courses mainly by private study, although Weston recalled that amongst his students were "schoolmasters on the way to a change of profession, others were law clerks, while some were taking the course in case at any time their then occupation should fail or become wearisome". ${ }^{40}$ Weston and his successors (all local practitioners) lectured alone until 1912 when an assistant lecturer was appointed. In 1922 a further assistant was added to the staff. ${ }^{41}$

In 1883 Auckland University College was established as a constituent college of the University of New Zealand. At the outset, the Council favoured establishing lectures in law, and during 18834 Judge Seth Smith delivered lectures on real property and equity until the pressure of work caused him to resign. ${ }^{42}$ Lectures were resumed only in 1898 when A McArthur commenced lectures in Jurisprudence and Constitutional History for fees only. ${ }^{43}$ McArthur continued until 1901, and he was succeeded in 1904 by H Dean Bamford who taught (also for fees only) Contracts and Equity in addition to McArthur's subjects. In 1911 Douglas Chalmers became the lecturer, and in 1913 he was joined by another Auckland graduate, Ronald Algie. They extended lectures to cover the full syllabus for the LLB and law professional examinations. By this stage there were over a hundred students attending some of the law courses and the law enrolments were the largest in New Zealand. In 1920, following petitions from the local District Law Society and the student body, Algie was appointed the first professor of law (without advertisement) and remained in this position (despite some controversy) until his resignation in $1938 .{ }^{44}$

As early as 1886 Robert Stout declared that Wellington "is the seat of Parliament and the seat of the Court of Appeal" and "might be prominent for its special attention to jurisprudence, to law"45 Stout's efforts in 1887 to pass a Wellington University College Bill were defeated by in the Legislative Council on the basis that "we have not got any more money to expend on high-class education in 
this colony". ${ }^{46}$ However, by the 1890s, the population of Wellington and its neighbouring regions equalled Canterbury and approached that of Otago, popular pressure grew for the establishment of a College, and the government was in a better financial position to fund the venture. ${ }^{47}$ In 1897, on the Diamond Jubilee of Queen Victoria, Wellington acquired its college and a name for it, and two years later Victoria College was affiliated to the University of New Zealand. ${ }^{48}$ Law tuition began in an unlikely way with Richard Maclaurin, professor of mathematics, who from 1899 added lectures in law to his other duties. ${ }^{49}$ The following year, on the prompting of Stout CJ, the University appointed Maurice Richmond to teach LLB subjects. ${ }^{50}$ At the 1904 New Zealand University Senate meeting, Stout CJ (as Chancellor) repeated his earlier suggestion that Wellington could become the national Law School, and "make provision for the more effective teaching of that important subject". ${ }^{51}$ In 1905, with the provision of funds from the government, the College Council created two chairs in law: a senior chair of law, covering Jurisprudence, Roman Law, International law, Conflicts and Constitutional Law and History, and a second chair of English and New Zealand law. The senior chair was given to John Salmond and the other to Richmond. ${ }^{52}$ Salmond was an extremely able teacher and a profound scholar, but his desire for the more practical aspects of law led to his resignation in 1907 (to become counsel to the Department of Parliamentary drafting). ${ }^{53}$ Maclaurin briefly succeeded to the chair of law (in addition to that of mathematics) and the position of dean of the Law Faculty, before his departure to Columbia University. In 1908, James Adamson was appointed to organise a Law School at Victoria College, and he served ("with solid and unimaginative persistence”) as professor of Jurisprudence, Roman Law, and Constitutional History until $1939 .{ }^{54}$ In 1910, on Richmond's retirement, the second chair was given to James Garrow, an "unexciting kindly man” and an outstanding "examination coach", who remained until 1929. ${ }^{55}$ The Victoria University College Law Faculty benefitted from the guidance of two full-time professors of law, and by the 1920s its law enrolments were on a par with those of Auckland and well ahead of those of the two South Island Faculties. ${ }^{56}$

Overall, however, the progress of university legal education in 
its first fifty years had been painfully slow. University tuition was generally limited and at times erratic, and it was conducted largely by part-time lecturers with poor library and other resources, who instructed overwhelmingly part-time students (many of whom were not employed in law offices). ${ }^{57}$ Even by 1925, Adamson asserted that "there is at present no Law School in New Zealand ${ }^{58}$ This state of affairs caused many students to prefer private coaches and correspondence studies to college classes even where classes were offered, obliging the University of New Zealand (in 1919) to make compulsory the keeping of terms (of attendance) in all subjects for the LLB degree. ${ }^{59}$ The New Zealand developments mirrored those in England where "most of the distinguished lawyers between about 1850 and 1950 were either not university graduates at all or had read subjects other than law". ${ }^{60}$ It has been suggested that in New Zealand the judges, in whose hands the remedy lay, were notoriously slow to become involved, the members of the legal profession "were too easily satisfied by employing, at low cost, law clerks who could study for their professional examinations and even for the law degree as part-time students", and overall "the belief that education in law should be done cheaply became deeply embedded in the universities". ${ }^{6}$

\section{KEY REFORMS AND DEVELOPMENTS (1920S TO}

\section{S)}

In 1925 a Royal Commission was appointed to provide information on the administration of university education. The Commission reported that the training of the legal profession required a sound and liberal course of general education, an intensive training of high quality in the principles and in the practice of their special work, and the acceptance of a body of ethical standards as a guide to professional conduct. The Commission considered New Zealand legal education deficient in the first two areas. It noted that "unless a marked change is effected in the legal education provided in the Dominion, [the term my learned friend] runs the risk of being regarded as a delicate sarcasm". ${ }^{62}$ The Commission also recommended a thorough strengthening of the legal courses, and the establishment of a properly staffed and equipped Law School at the most suitable 
centre. ${ }^{63}$ The comments of the Commission led to a revision of the LLB and solicitors' courses. In 1926 the LLB was expanded into four divisions comprising fifteen subjects which had to be taken two to four at a time. ${ }^{64}$ The solicitors' qualification was largely the same except that Latin, Roman law and International law were not compulsory subjects. Both barristers and solicitors had to pass in conveyancing and bookkeeping. The "back-door" entry method was practically eliminated in that henceforth solicitors who wished to be admitted as barristers had to make up the major differences between the two qualifications. ${ }^{65}$ By the late 1920s, the LLB degree had eclipsed the solicitors' course as the qualification taken by the great majority of lawyers. ${ }^{6}$

The Commission also recommended a Council of Legal Education (along the lines of the Council existing in Victoria), comprising two judges appointed by the Chief Justice, two nominees of the New Zealand Law Society and two university teachers nominated by the University Senate, as the best method of prescribing and safeguarding legal education. This Council would assume the powers over legal education then legally in the hands of the judges concerning courses of study, examinations, and the educational and practical qualifications of candidates for admission as barristers and solicitors. ${ }^{67}$ The Council of Legal Education was established in terms of the New Zealand University Amendment Act 1930, and regulations governing its proceedings appeared in 1932. The Council was allowed to make recommendations to the University Academic Board, and the Board could not make recommendations to the University Senate without first giving the Council reasonable time in which to comment. However, under the Law Practitioners Amendment Act 1930 the University Senate had the responsibility of making final decisions on courses and examinations for admission. ${ }^{68}$

The Council's first major task was to collect information about systems of legal education in other British countries and the United States of America. In its report of 1934, the Council proposed that the preliminary examination for barristers should be increased from two to five arts units and required for solicitors as well, and recommended a course of practical training. To improve the system of examining, the Council proposed that examiners in the professional subjects be appointed on the recommendation of the 
Council and "be informed that they would be expected to set papers designed to minimise the reproduction of memorised material. ${ }^{69}$ The Council's efforts helped to upgrade legal education, and in 1935 the LLB degree was made a five-year degree which included Latin plus four non-law units. ${ }^{70}$ But the Council's opposition to the idea of attendance at one Law School (on the basis of inconvenience and possibly undue hardship) meant that education was left to the constituent colleges. Further, the Council was essentially concerned with questions of examination, and law students were left to study when and where they liked and the colleges were left as uncoordinated and seriously under financed institutions. ${ }^{71}$

Through to the 1950s, the two North Island law faculties continued to have an advantage not possessed by the two South Island faculties: the presence of full-time professorial staff. ${ }^{72}$ The academic pre-eminence of the North Island faculties was reinforced in the 1930s and 1940s with the appointment of young and dynamic professors: Victoria acquired James Williams and Robert McGechan $^{73}$ in Auckland Julius Stone and then Geoffrey Davis were appointed. ${ }^{74}$ McGechan has been singled out as "the most influential figure in New Zealand legal education ${ }^{75}$ Amongst his achievements were the advancement of the autonomy of the New Zealand University Colleges, the institution of the combined BA LLB degree and the promotion of co-operative research in law and social sciences, the pioneering of the "case method" of law teaching, and the establishment of administrative law in legal training. McGechan believed that the lawyer being trained needed "constant reminder that there is a larger world back of the law" which had to be understood. Furthermore, in his view, one of the major tasks of the law was "reconciling and integrating human ideals", and so for him the essence of legal study "was to begin with a concrete case in all its native complexity and see the struggle of competing principle within it”. ${ }^{76}$ McGechan presented and defended his American-style "case method of study in an article published in the first edition of the Victoria University Law Review in $1953,{ }^{77}$ and here he articulated what he saw to be the most important aspects of law teaching. He advocated the case method because "we wanted the student to learn actively by doing, not passively by repeating; because we wanted him to learn the 
techniques, the way of the law and not so many legal rules; because we wanted him to learn for keeps, not to pass examinations”. He added that the student could learn to think in class and aloud, get to know and learn from other students, enjoy the experience of learning, and have the scope to explore the political, economic and social background of a legal decision and ask "whether it is a good and sound decision not only for its logic in law but in its justice and in its practical bearing on the lives of twentieth century New Zealanders". He believed that the case method also allowed the teacher to get "to know his students as individuals", and remarked that "we - I hope - continue to develop as teachers" ${ }^{78}$ Not surprisingly, by the late 1940s, Victoria University College, under the guidance of McGechan and his capable colleagues, could claim to have the premier academic legal institution in the country. ${ }^{79}$

In 1941 the North Island academics pressed for a review of the long-standing system of common external examinations set by people other than those engaged in teaching (and often conducted by lawyers unskilled in the art of examining). The professors pointed out that such a system narrowed the range of topics examined, limited the standard to that of a particular text, was conducive to "cramming", and was inappropriate in view of the different teaching methods adopted throughout the country. The professors proposed a system in which the individual law teachers largely determined the scope and composition of the papers and marked the scripts, subject to external examination. ${ }^{80}$ The proposals of the northern professors were opposed by the Law Faculties of Canterbury and Otago, mainly on the bases that they were cumbersome and would ultimately lead to different standards for qualification to practise in the same profession. ${ }^{81}$ The system of examining LLB subjects approved by the University in 1941 was a compromise. Each subject would have an external examiner, to whom each head of department could submit draft questions, and after further consultations the external examiner would finalise the paper. The scripts of each college were first to be marked internally, heads of department could make representations on behalf of deserving students, and the final decision on the scripts was taken by the external examiner. ${ }^{82}$

Further controversies involving the more conservative Law Societies and Law Schools of the South Island concerned the place 
of cultural subjects such as Roman law and Latin. In 1941 the solicitors' professional course was given a greater cultural dimension with the inclusion of three Arts units (comprising Latin I and English I) and Roman Law. This was in opposition to the wishes of the Otago Law Society, which in 1949 prevailed to the extent that Roman law was deleted for solicitors. In 1947 the Professorial Board of the University of New Zealand set up a committee to look at the teaching of Latin in schools. It reported in 1951 that, whereas before the Second World War Latin was nearly universal for the upper forms of New Zealand secondary schools, by 1951 it had all but disappeared from state schools. Despite opposition from the Otago Law Faculty, which wanted to retain Latin as a compulsory subject for barristers, Latin was removed as a compulsory subject in $1952 .{ }^{83}$ In 1960 , Legal System replaced Roman Law as the foundation course in the law curriculum, and in subsequent years the choice of Roman Law as an optional subject all but disappeared. ${ }^{84}$

\section{THE MOVE TO SEPARATE, LARGE-SCALE, FULL-TIME}

\section{ACADEMIC LAW SCHOOLS (1950S TO THE PRESENT)}

By the 1950s the move towards the devolution of powers from the central University of New Zealand to the constituent colleges, evident for some time in other faculties, finally affected the law faculties. In 1961 the University was dissolved and the constituent colleges became independent entities. ${ }^{85}$ In view of the repeated changes which the University imposed on the LLB degree during the 1950s, it was suggested that the end of the University "was perhaps just as well”. ${ }^{86}$ However, it was recognised that it was important that there be comparability of standards and course content amongst the law qualifications offered by the newlyindependent Universities. Therefore, in 1960, agreement was reached for the continued existence of the Council of Legal Education, comprising representatives of the judiciary and the New Zealand Law Society Council (as before) and the deans of the faculties of law in the four independent universities. Its responsibilities were to include the approval of qualifications for admission of barristers and solicitors and the advising of the universities on matters relating to legal education. Each university 
was to have full control of its law degrees, and examinations were to be conducted by the university teachers concerned subject to assessors appointed by the Council of Legal Education on the nomination of the Law Society. ${ }^{87}$

During the 1950s, the number of law students grew significantly, and this was a prelude to even greater growth in the 1960 s and beyond, when women enrolled in increasing numbers. ${ }^{88}$ In 1951 there were around 200 students (with a first year enrolment of less than ten) in Auckland and around 300 other law students in New Zealand, but by 1970 Auckland alone had 800 students enrolled (despite selective admission) and a graduating class of nearly $100 .^{89}$ By the late 1970 s there was concern expressed at the numbers of law graduates, and the realisation that not all could be absorbed by the legal profession and that some would go into other spheres such as business and government service. ${ }^{90}$ At the same time, the concept of full-time attendance of law students took hold. A conference between representatives of the New Zealand Law Society and the University of New Zealand in 1954 agreed that "while no law student should be required to attend the University as a full student there is considerable advantage to a student who undertakes one or two years of attendance as a full-time student". ${ }^{91}$ This view was favoured by the Council of Legal Education. ${ }^{92} \mathrm{~A}$ Committee appointed in 1959 to investigate the New Zealand University learned that the number of full-time law students had risen to nearly a third (higher than in commerce). ${ }^{93}$ In the light of evidence which showed that full-time students of all faculties did uniformly better than part-timers, the Committee recommended that in all faculties the universities should regard the education of full-time students as their primary concern. ${ }^{94}$ The Committee's proposal that the government provide more generous bursaries was accepted, and the new bursary scale allowed many more students to come to university full-time. ${ }^{95}$ In the early 1960 s it became the norm for the first three years of the LLB degree to be fulltime, and by 1970 an increasing number of students were completing their entire degree full-time. ${ }^{96}$ In 1965 the Council of Legal Education marked the demise of the old solicitors' qualification by making graduation in law at university compulsory, and this development effectively unified local qualifications of barristers and solicitors. ${ }^{97}$ As law students became more fully integrated into academic life, 
they increasingly saw the value of advanced non-legal studies, and by the 1990s a significant proportion were graduating with double degrees. $^{98}$

Mirroring developments in the student body, law faculty staff increased in numbers and became increasingly fulltime. In the immediate post-War period, law students still received most of their instruction from practitioners: in 1951, there were only two full-time law teachers in Auckland, four at Victoria and none in the South Island. ${ }^{99}$ By 1970, most law teaching was done by permanent full-time teachers: by this time twelve established chairs had been created (three at Canterbury and Otago), there were more than twenty-five full-time teachers at both Auckland and Victoria, and twelve in the South Island. ${ }^{100}$ At Otago, the first moves in the direction of a professor began in 1953 and culminated in 1959 with the appointment of Francis Guest, a local practitioner with an outstanding reputation. ${ }^{101}$ Under Guest and his successor, Peter Sim, ${ }^{102}$ the Law School grew from one full-time member to 11 fulltime members and eight part-time staff in 1978. At Canterbury, the first professor (Hamish Gray) was appointed in 1957, and subsequently two chairs were created in 1968 (filled by George Hinde and Robin Caldwell) and one in 1973 (filled by John Burrows). ${ }^{103}$ In Auckland, Jack Northey joined Geoffrey Davis in 1954 as second professor of law. Northey had been assistant secretary to Cabinet and "was to become a skilful tactician in the manoeuvres of academic politics". ${ }^{104}$ After two further lecturers were appointed in Auckland in the late 1950s, the 1960s saw no fewer than eighteen appointments (with only five departures). ${ }^{105}$ Expansion continued in the 1970s with the result that the Auckland Faculty became the largest in New Zealand. ${ }^{106}$ Victoria University Law School continued to attract scholars who made a major contribution to academic legal life, including Colin Aikman, Robert Quentin-Baxter, and Kenneth Keith. However, a number of leading Victoria academics subsequently moved into private practice and official positions. ${ }^{107}$

The creation of full-time academic positions in law stimulated academic legal research and publications. In 1965 Professor Derham (Dean of the Monash University Faculty of Law) pointed to the need for improvement in facilities and opportunities for research work. ${ }^{108}$ In the late 1960s and early 1970s, advances were 
made. Library resources grew, so that by 1970 all of the Law School libraries were at least ten times as strong as they were in 1951. ${ }^{109}$ The introduction of LLB Honours degrees led to more students receiving training and experience in research, and government funds were provided for law reform research. ${ }^{110}$ From the 1960s, further outlets for academic publications were provided with the commencement of the New Zealand Universities Law Review (in 1963), the Otago Law Review (in 1965), the Auckland University Law Review (in 1967) and the Canterbury Law Review (in 1980). ${ }^{111}$ At Auckland (following a law students' conference in 1965), the Legal Research Foundation was established, and this came to oversee the production of the New Zealand Recent Law Review, research into particular areas with a view to reform, and the arranging of conferences and dinners. ${ }^{112}$ During the 1960 s and 1970s, an increasing number of textbooks reflecting New Zealand (as opposed to English) law were published by New Zealand academics. ${ }^{113}$ In 1969, Turner $\mathrm{J}$ remarked on the new research emphasis in the functions of law teachers, "indicative of a new dynamism in legal education which was sadly absent from the rather duller type of scholarship which was once thought sufficient for the education of the law student”, though he did warn against the frantic "rat-race" of publication for its own sake. ${ }^{114}$ Conferences were held on legal education, and fulltime academics introduced new teaching methods. ${ }^{115}$

With the advent of more full-time staff and increased resources in Law Faculties, there were growing calls for a broader vision of legal education. Following the earlier lead of McGechan, legal academics argued for a shift from the traditional focus of legal education on the uncritical acquisition of legal rules and processes necessary for legal practice to a critical, conceptual and contextual understanding appropriate to law and other fields. In 1967 Professor Coote of Auckland called for law teachers to foster in their students qualities of "intellectual vigour and adaptability", with a view to effective decision-making, and to show New Zealand lawyers "the way out of the ivory tower which the common law system has built around them" by opening "the law to scrutiny by the light of other disciplines" 116 In 1973 Professor Ivor Richardson of Victoria stated that the lawyer needed to have a broader education and an under- standing of social and economic 
policies; and he believed that the law course should be recognised as a multi-purpose course (not simply for professional training) which developed the skills of research, analysis and the forming of judgments important for anyone involved in making decisions". ${ }^{117}$ Commentators have seen in the development of New Zealand's legal research and teaching the influence of American legal education, which had become "dominantly full-time, university, graduate-level education, taught by dialogue rather than lecture" as early as the end of the nineteenth century. ${ }^{118}$ Professor Kenneth Keith of Victoria remarked that "the American method, building on the best of the old world inheritance, challenges us to see the law in context, to examine both the detail and the wide picture, and to test the law, so that in our own land it may mediate continuity and change, heresy and heritage, and provide the wise restraints that make us free". 119

The shift in academic emphasis came to have direct implications for the content of the LLB degree. From the early 1970s the New Zealand law schools, following trends elsewhere, increasingly felt the need to provide flexibility in the LLB degree in the form of optional courses. This was supported by those students who had discovered a particular interest and wished to shape their degree course so as to give their studies a particular emphasis and by staff specialising in particular fields who wished to offer courses in their areas of speciality and promote research in those areas. There was increasing recognition that no course of theoretical study could or should attempt to cover all the fields that a lawyer could work in, and that provided law students were taught legal principles and certain core subjects there was space for optional courses. ${ }^{120}$ The Auckland Law School began to offer advanced optional courses for those who wished to deepen their knowledge in particular areas, and this concept was extended by the other Law Schools for honours students. In 1987, a Report commissioned by the New Zealand Law Society and the Council of Legal Education (the "Gold Report") listed as one of its concerns that "the New Zealand law degree is encumbered by an over-extensive list of prescribed courses", and proposed that "only those courses which serve as foundations of law study, its concepts, policies, values and theories need to be prescribed". ${ }^{121}$ This proposal was duly accepted, and from 1988 the compulsory core courses for admission were 
reduced to seven and the remainder of the LLB degree comprised a wide range of options. ${ }^{122}$

The conservative, English-based New Zealand legal profession, and the legal education which it supported, traditionally showed little interest in or concern for Maori customs, concerns or issues. However, by the 1970s, in the context of greater public consciousness of the Treaty of Waitangi and Maori pressure for recognition of their rights, there were calls by legal academics to move beyond the English-oriented "camaraderie [which has] obscured from us the realities". ${ }^{123}$ In 1987 the Gold Report acknowledged the need for New Zealand legal education to incorporate a Maori dimension by advising that there should be a special section of the professional legal studies course on Maori language and culture. ${ }^{124}$ In 1988, Richardson J, Chairman of the Council of Legal Education, included amongst his list of crucial issues of modern New Zealand legal education "valuing cultural diversity and recognising the unique character of New Zealand founded on the Treaty of Waitangi". ${ }^{125}$

It was in the context of the above developments and pressures for change that New Zealand's fifth law school was established at Waikato University in $1990 .{ }^{126}$ The immediate stimulus for the new Law School was a letter of 1986 from the Auckland District Law Society to the Vice-Chancellor of the University of Auckland, expressing concern at the lack of law graduates available to enter legal practice, especially in the Waikato/Bay of Plenty regions. This lack was caused partly by the policy of Auckland and other Law Schools to limit numbers of students enrolling for law qualifications. The matter came to the attention of the University of Waikato, which had had requests from the local profession and from within the university for the establishment of legal studies, and the University decided to set up a committee to prepare the case to establish a law school. Research conducted by the committee confirmed the demand for more law graduates in the region, and in 1988 the committee presented its report in support of the new school. This report, entitled Te Matahauariki, ${ }^{127}$ advocated a new approach to legal education, which examined law in the context of the society in which it operates and which took account of the growing emphasis on biculturalism that was emerging in New Zealand. While the report was considered by the authorities, 
teaching of the Auckland Legal System course commenced at Waikato University at the beginning of the 1988 academic year. In April 1989, the Council of Legal Education, having considered the Waikato report and a proposal for a new Law School from Massey University, recommended the establishment of a fifth Law School but did not indicate a positive preference for either Waikato or Massey. Later that year the University Grants Committee recommended the Waikato proposal and the government duly approved the establishment and funding of the Law School at Waikato. On 1 July 1990 the school was formally established under a Foundation Dean, Margaret Wilson, and in 1991 the LLB degree was launched. The Waikato degree consciously strove to translate the ideals expressed in Te Matahauariki into reality: to achieve "a more even balance between the demands of a professional education and the need to acquire skills that can be used not only in the legal system but also in the social, economic, cultural, and political systems”, having regard to multi-disciplinary knowledge and biculturalism. ${ }^{128}$

However, as the Waikato Law School itself recognised, the emergent academic law schools retained their traditional responsibility of imparting the skills and knowledge required in an essentially applied discipline, thus forcing the law schools to face "in two directions, inwards towards the intellectual life and outwards towards the law in action as opposed to the law in the books". ${ }^{129}$ In 1967, Brim Coote (professor of law at Auckland University) parallelled the New Zealand situation with the English system where law teachers were "regarded by the profession as hopelessly academic and by their university colleagues as hopelessly unacademic”. ${ }^{130}$ Leading law academics reflected the need for law faculties to remain in tune with professional practice: Dr B D Inglis, retiring professor of English and New Zealand Law at Victoria University argued against the university "becoming inward-looking and believing that is an end in itself”, and his successor, Ivor Richardson, believed that law schools could not "function effectively unless a good proportion of the staff have themselves had reasonable and recent experience of the practice of law". ${ }^{131}$ At the same time, legal academics bemoaned the fact that "compared with other disciplines we do not have, and are not perceived as having, a highly developed tradition of committed and 
sustained scholarship which is central to the culture of academic law”. ${ }^{132}$ In 1992, Professor Grant Hammond of the Auckland Law School remarked that, while he hoped that the links with the profession would be maintained, "the walls between us and other Departments need to come down more rapidly in this institution, though I fear that could be said throughout the academy in this country". 133

The development of a system of largely full-time study in academic legal institutions also had mixed blessings for the bulk of the law graduates who then proceeded into the legal profession. They undoubtedly had a richer and broader education of higher academic standard than their forebears had, but they arrived in legal practice with little or no idea of how legal offices worked or how their theoretical learning could be put into practice. ${ }^{134}$ North J, in 1971, observed that with the recent tendency for law students to remain fulltime, there had emerged "here and there some graduates [who] tended to become narrow and technical and unable to form a reliable judgment of the weight of factual evidence and found it difficult to consider alternative legal consequences in a situation where the facts were not crystal clear". ${ }^{135}$ The professional practical training which (in terms of the Professional Examination in Law Regulations 1966) lawyers were required to take was done after the LLB in a year-long course of professional subjects completed parttime while working in law offices. ${ }^{136}$ The level of training which they received while completing the professional subjects was very much dependent on how well the particular firm carried out that task, and the contemporaneous growth in the number of barristers who went out into sole practice depleted the number of legal firms able to give useful guidance to young lawyers seeking to specialise in advocacy. ${ }^{137}$ Thus, in 1977, the New Zealand Law Society wrote to the Council of Legal Education asking that further practical training be provided by the University Law Schools. The following year the Council responded by asking each of the Universities and the University Grants Committee to increase resources for practical training and by asking the Law Society "to give further consideration to the part it can play and the contribution it can make in discharging its basic and continuing responsibility to train its members". ${ }^{138}$ In response, the Society decided to build upon the experience it and the District Law Societies (notably Auckland) had 
by then acquired in successfully operating continuing legal education programmes. ${ }^{139}$ In 1979 the Law Society Council approved the Post Admission Practical Training scheme (which came to be known as LawPrac) under the control of a fulltime Director of Education. ${ }^{140}$ At the same time, law faculties at Otago and Victoria established legal advice and referral services for the public, providing valuable experience for law students. ${ }^{141}$

However, these programmes did not provide an adequate substitute for the inadequate system of pre-admission professional education that lawyers received. Likewise, mounting evidence showed that many law graduates considered that their law school education neglected fact-finding and drafting techniques, organisational skills and "interpersonal" skills of effective oral communication, ability to interview people, and ability to negotiate. ${ }^{142}$ Further, with the increase in law student numbers, not all graduates were able to find jobs in law offices and complete the course in conjunction with legal practice. Cognisance was taken of overseas schemes in England and Australia which offered full-time intensive professional training in less than a year. ${ }^{143}$ In 1982, the New Zealand Law Society submitted to the Statutes Revision Committee on the Law Practitioners Bill that it conduct a compulsory law practical scheme. In the face of opposition from law deans and students, the Committee decided not to accept this proposal. However, the Committee acknowledged the Law Society's complaint about the difficulty in obtaining changes to legal education to provide for practical training, and so it proposed that the Minister of Justice be empowered to require the Council of Legal Education to inquire into and report on any matter of legal education. ${ }^{144}$

In 1986 the New Zealand Law Society and the Council of Legal Education called upon Professor Neil Gold, a Canadian legal academic, to report on professional legal training in New Zealand. Gold's Report (of January 1987) declared professional training in New Zealand to be:

a poor sibling of both the academic and practising worlds. When the salutary decision to make law study a full-time activity was made, little was done to bridge the gap between academic grounding and the development of practical and professional skills, knowledge and the attitudes which are the requisites of competent practice. Hence, the professional courses are tokenistic, superficial and under-supported. 
...there is overwhelming agreement that newly admitted barristers and solicitors simply do not have the skills necessary for proficient practice. Reiterated, almost ad nauseam, is the need for client relation skills, fact marshalling and analysis skills, general problem solving capability and the arts of persuasion applicable to those who negotiate and advocate. ${ }^{145}$

Gold's recommendations for a "more systematic, more carefully structures, goal-oriented programme of professional preparation”, which addressed the needs of practitioners, were duly accepted by the Council of Legal Education. ${ }^{146}$ The Professional Examinations in Law Regulations 1987, which came into effect in 1988, instituted a new system of professional training. This involved a full-time course following the LLB degree, conducted twice each year at Auckland, Victoria, Canterbury and Otago Universities. The course was controlled by an Institute of Professional Legal Studies, established as a sub-committee of the Council of Legal Education, and operating through branch institutes at each of the university centres. In 1990, a review of the Institute was undertaken by Christopher Roper (former Director of the College of Law in Sydney), and in the following year modifications were introduced. The course in its revised form now runs for thirteen weeks (involving three intakes per year), and covers two modules, namely litigation and commercial/property law, and including a seminar on legal research. ${ }^{147}$

\section{CONCLUSION}

The history of New Zealand legal education has revealed that, like the Roman god Janus, it has had two faces pointing in different directions. ${ }^{148}$ The reflective, academic face of legal education, which was relatively insignificant for much of New Zealand's legal history, has in recent decades assumed major importance. There has been growing emphasis on training in critical legal reasoning and general principles and concepts, with a view to employment in many different areas. As law faculties have been more firmly integrated into the academic life of universities, there has been increasing recognition by both staff and students of the value of non-legal studies and the need to examine law in its broader, social context. At the same time, the practical, professional face of legal education, traditionally the stronger element, has maintained a firm presence. This has been evidenced, for example, by the continuing 
supervisory role of the Council of Legal Education and by the demand of the legal profession for effective post-graduate training in professional skills. The awesome challenge of modern New Zealand legal educators is to fulfil their professional commitments with expertise and a sense of practical reality while remaining true to their newly enhanced vision and ideals: in other words, to convey an understanding of "what is" and to stimulate the promise of "what might be". ${ }^{149}$ Neil Gold, in his report which had major consequences for modern New Zealand legal education, commented:

Law education is both deep and varied. Because law cannot helpfully be abstracted from its social, economic and political milieu, it cannot be truly understood except in the context of human aspiration and endeavour. Yet it is also a practical subject which seeks solutions to difficult problems of policy and justice. In the best of all possible worlds it is a general legal education which prepares graduates to face and adapt to change in all aspects of their lives, but especially throughout their legal careers. ${ }^{150}$

* Associate Professor of Law, Waikato University, New Zealand.

(C) 1993. (1993) 4 Legal Educ Rev 223.

1 H Kirk Portrait of a Profession (London: Oyez Publishers, 1976) 645.

2 BJ Cameron, “Appeals to the Privy Council - New Zealand" (1970) 2 Otago Law Rev 184.

3 Cf William Blackstone: "if practice be the whole he is taught, practice must also be the whole he will ever know": see Commentaries 15 ed 32-3.

4 MJ Cullen Lawfully Occupied (Dunedin: Otago District Law Society, 1979) 16. Legislation continued to list separately the qualifications and admission requirements of barristers and solicitors until the Law Practitioners' Act 1982.

Supreme Court Ordinances 1841 and 1844, and see RB Cooke Portrait of a Profession (Wellington: A H Reed, 1969) 138-9.

6 Appendix to the Journals of the House of Representatives (AJHR) 1860: A 1-3.

7 Kirk, supra note l, at 54 .

8 Id at 54-6 and 65.

9 Appendix, supra note 6, at 3-4.

10 Sections 6 et seq (barristers) and 16 et seq (solicitors).

11 Rules 13 and 21, New Zealand Gazette 1864, 62-4. See Kirk, supra note 1, at 53-6.

12 The course prescriptions for barristers not admitted overseas required knowledge of the "Theory and Practice of Civil and Criminal Law of England and New Zealand, including "a knowledge of the leading decisions in the Court of Appeal in New Zealand”: see [1875] Colonial Law Journal vol 1 part II, 34. The examination for those admitted overseas examined the relationship between English and New Zealand law and local statutes such as the conveyancing ordinance: see P R Spiller Chapman Legal Family (Wellington: Victoria University Press, 1992) 261.

14 The Law Practitioners' Amendment Acts 1865 and 1866 allowed service as 
judge's secretary or clerk or as registrar or deputy-registrar to count towards the period for sewing articles. The Law Practitioners Act 1882 dropped the requirement of articles. See AJHR 1925: E 7A 45.

AJHR 1925: E7 A 45. Wilkie, 1920) 100

Cullen, supra note 4, at 114-6. Henry Chapman told his son Frederick, who had been admitted to the English bar and had to write the examination in New Zealand law, that the examination was "really a humbug": see Spiller, supra note 12 , at 261.

Kirk, supra note l, at 65.

Minutes of the Senate of the University of New Zealand (MSUNZ), 8 April 1874.

In 1883 examinations were prescribed as follows: Latin, English/Mental Science, Jurisprudence, and Constitutional History (year 11); Roman law, International law and Conflict of Laws, English Law (Contracts) and English Law (Torts) (year III); and Law of Real and Personal Property, Law of Evidence, Criminal law, and Equity (year IV). (In1886 it was decided that the term English law was to be defined as the Law of New Zealand). In 1888 Statute Law in New Zealand and the Practice and Procedure of the Courts in New Zealand were added to the degree. See Cullen, supra note 4, at 120.

Rule 3, 1889 New Zealand Gazette 725-6 (in force l June 1890). See H Parton The University of New Zealand (Auckland: Auckland University Press, 1979) 47, and JC Beaglehole The University of New Zealand (Wellington: New Zealand Council for Educational Research 1937) 113.

221889 New Zealand Gazette 725-6. In 1894 the separate examination in Statute Law was dropped from the LLB: see Cullen, supra note 4, at 121.

23 In the 1907-8 New Zealand University examinations there were 202 solicitors' law professional candidates and 61 LLB candidates; in 1915 the figures were 293 and 56 respectively; but by 1923 they were 155 and 229 respectively: see MSUNZ 1907-8, 1916 and 1923. Prominent lawyers who qualified in law without an LLB included Stout CJ, Skerrett CJ, and all of the locally-qualified judges appointed prior to 1925. In 1907 the LLB degree was recast into divisions, and the second (more practical) part could be taken before the first (more academic) part, thus allowing those who had started out on the professional route to switch to the degree: see Cullen, supra note 4, at 122.

In 1871 the population of Otago was 69400 (down from 76900 in 1863), while that in Auckland was 62 300, Canterbury 46 800, Nelson 27700 and Wellington 24 000: see Beaglehole, supra note 21, at 5.

Id at 19. In 1874 the University of Otago became a constituent college of the University of New Zealand, with the result that control over the structure of examinations (though not the form of teaching) passed to the national body: see Cullen, supra note 4, at 116.

26 The committee believed that nearly all of the 30-40 law students in Dunedin would attend university classes if established: see Beaglehole, supra note 21, at 100. In 1872 the University Council even considered the idea of establishing a Law School: see Cullen, supra note 4, at 117.

Id at 117. In 1874 a committee composed of HS Chapman $\mathrm{J}$ and two lawyers, AC Strode and JH Harris, decided against a second appointment: Cullen, supra note 4 , at 117.

Spiller, supra note 12, at 162 and Cullen, supra note 4, at 117 and 123.

Cullen also suggests that the "timidity" of the university was a factor, and notes that at this stage JW Salmond and AR Barclay both offered their free services: see Cullen, supra note 4, at 117.

30 Id at 229-230.

31 JB Callan declared that these were the "bad old days when the teaching of law 
was hardly tolerated at [Otago] university much less encouraged: see Cullen, supra note 4 , at 131.

Id at 231. From 1914 to 1920 the Faculty of Law was joined with the Faculty of Commerce: see Cullen, supra note 4, at 126.

33 The number of students attending law lectures rose from 14 in 1911, to 40 in 1912, to 53 in 1919, to 76 in 1925. In 1921 the staff included future judges JB Callan, HE Barrowclough and FB Adams and future dean AC Stephens: see Cullen, supra note 4, at 127 and 285.

34 Id at 131.

35 Id at 129.

36 GW Keeton, “Charles James Foster” [1966] NZLJ 568, and J H Farrar, “Dr C J Foster - Canterbury’s First Law Teacher” (1980) 1 Canterbury Law Rev 1,5.

37 Farrar, supra note 36, at 13, and I Matson, "University of Canterbury Faculty of Law: An Historical Note” (1980) 1 Canterbury Law Rev 1. In 1882 the Canterbury District Law Society instituted a scheme of prizes to the best law candidate irrespective of where he lived (though from 1912 the Society awarded gold medals only to Canterbury graduates).

38 GT Weston, “Early Law Tuition in Canterbury” (1958) 34 NZLJ 71.

39 Weston recalled that at hi request he was supplied with the New Zealand statutes and law reports, but that "otherwise, there were only a few old books, such as Sir Henry Maine's works and Wheaton's International Law, in the College Library, which was housed in the College Hall and was under little or no supervision” (id). Weston had an enlightened approach to his law teaching: he remarked that he "endeavoured by question and answer to make the students teach themselves ... how to apply [legal] principle and to understand the reasons why the principle should or should not apply to the case before them”: id at 72 .

40 Id at 71 and WJ Gardner, ET Beardsley, and TE Carter, A History of the University of Canterbury 1873-1973 (Christchurch: University of Canterbury, 1973) 97.

41 Matson, supra note 37, at 196.

42 K Sinclair A History of the University of Auckland 1883-1983 (Auckland: University of Auckland Press, 1983) 37.

43 Id. The examination paper set by McArthur in 1899 has been described as "an extraordinary combination of elementary jurisprudence, constitutional and international law and legal history": id at 84.

44 In 1933 the student periodical Craccum alleged that Algie and fellow law teacher LK Munro wrote the notes for a local correspondence coaching college and that the students were virtually compelled (in the absence of suitable textbooks) to enrol at the college in order to get the notes. A committee of inquiry did not find evidence to support the charge of exploitation of students, although commentators have asserted that the charges were substantially correct: see Sinclair, supra note 42, at 147. See also R Algie, "Legal Education” (1925) 1 NZLJ 48, and the assessment of Algie by AP Blair in Cooke, supra note 5, at 195-6.

Beaglehole, supra note 21, at 33-4.

46 JC Beaglehole, Victoria University College (Wellington: New Zealand University Press, 1949) 10.

47 Id at $11-16$.

48 Parton, supra note 21, at 25.

49 Cooke, supra note 5, at 188-9.

50 Richmond, who had taken BSc honours at University College London, had returned to New Zealand to study law and commence practice, but he obtained a law degree only in 1904. It was said that he lacked the personality and the technical skill as a lecturer to satisfy the demands of his law students: "what the 
law students of his day wanted was a degree as swiftly as possible, with no nonsense of philosophy about it, and the man who gazed at his feet as he groped for the exact, the honest, the elusively truth-laden word was not precisely the man for them”: see Beaglehole, supra note 46, at 50-1). See also Cooke, supra note 5, at 189-190.

51 Beaglehole, supra note 21, at 244-5.

52 Beaglehole, supra note 46, at 99-100. Francis HD Bell was instrumental in approaching the Premier for government funds.

53 Id 100-1.

54 Id 102 and Cooke supra note 5, at 191-3.

55 Beaglehole, supra note 46, at 104 and Cooke, supra note 5, at 190. Garrow published extensively on New Zealand law, from the time of his first book Real Property in New Zealand (1913). It was said that the association with Garrow established Butterworths (which had had an office in Wellington since 1914) on a firm base: see [1984] NZLJ 120. Garrow was succeeded by HH Cornish: see Cooke, supra note 5, at 193-5.

56 In 1921, there were 60 LLB students at Auckland, 58 at Victoria, 22 at Canterbury and 6 at Otago: see MSUNZ 1921,52-3.

57 Adamson, before the Education Committee in 1913, protested that "Canterbury gets $£ 3000$ for engineering; Otago gets ...nearly $£ 4900$ for medicine”, but that Victoria College in respect to law was "the Cinderella”. In 1913 the Victoria College library contained 1258 law books and periodicals, and the other three colleges had 111 altogether: see AJHR 1912: E-7A, 10 and 1913: I-13A, 48-9, $62-3,65-7,83$ and $86-8$. In the 1930s the Victoria College student magazine Spike published an article entitled "Untwisted Teaching" which criticised the teaching of the Law Faculty: see Beaglehole, supra note 46, at 218. At Victoria College only $52 \%$ of the students were employed in law offices, and many of the remainder were state servants: see Parton, supra note 21, at 47.

Id and AJHR 1925, E-7A, 51.

59 MSUNZ, 2 February 1919.

60 This was despite the fact that the first Chair of English Law at the University of London was appointed in 1928, and degrees in English Law were offered at Oxford and Cambridge from 1850 and 1858 respectively: see JH Baker, An Introduction to English Legal History (London: Butterworths 2nd ed, 1979) at 148-9.

61 Parton, supra note 21, at 34.

62 AJHR 1925: E-7A, 44. The Commission's findings were born out by the fact that Victoria admitted practitioners from Britain, Ireland and the other Australian states, but required New Zealand graduates to work as clerks for five years and be re-examined in law.

63 Id 84-7. The proposal of a Council had been foreshadowed 50 years before by Frederick Chapman, Otago University's second law lecturer: in 1876 he had suggested a mixed board from the university and the judges to control legal education: see Cullen, supra note 4, at 117.

64 The subjects were: Division I: Latin, English or Philosophy, Jurisprudence, and Constitutional History and Law; Division E Roman law, Property (2 papers), and Contracts (2 papers); Division III Torts, Criminal Law, Company Law and Bankruptcy, and Trusts and Wills; Division IV: Evidence, Practice and Procedure, International Law, and Conflict of Laws: see Cullen, supra note 4, at 130.

$65 I d$

66 MSUNZ 1929 82-3.

67 JB Callan and the Otago District Law Society had suggested the idea of the Council as it was afraid that the constituent colleges of the university might become autonomous universities, and so result in lack of uniformity: see Cullen, 
supra note 4 , at 129 .

Id 131.

Parton, supra note 21, at 72.

Cullen, supra note 4, at 133.

Id 133 and 141.

In 1928 Victoria had 449 students, 2 professors, 6 lecturers and 1 assistant; Auckland had 620 students, 1 professor, 4 lecturers and 1 assistant; Otago had 336 students and 12 lecturers; and Canterbury had 112 students and 6 lecturers (A Bell and TA Barrow, Report on the Finances of the University and its Constituent Colleges (Wellington: 1928) 23). At Canterbury, long-serving heads of department were AS Taylor (1928-36), KM Gresson (1936-47) and LW Gee (1947-55). Amongst the notable part-time lecturers there was AL Haslam (D Phi1 Oxon) who lectured 1936-50. At Otago, long-serving deans were John Callan (1924-33) and Aubrey Stephens (1935-59), the latter being the last parttime dean.

Williams was born in Wellington, graduated LLB and LLM at Auckland University, and then graduated $\mathrm{PhD}$ at Cambridge University. He was Professor of Law at Victoria 1935-42 and again 1946-50, before becoming Principal and later Vice-Chancellor of Victoria. Cooke, in his "Tribute to Dr James Williams" [1976] NZLJ 186, wrote that Williams' Contracts book had analytical substance and a lucid and even style, and that Williams "had the teacher's one priceless and indispensable gift. mainly because of the sheer quality of his thought, he made the pupil interested". See also Cooke supra note 5, at 199-200. For McGechan, see infra note 75.

Stone was a graduate of Oxford, Leeds and Harvard, and was Dean and Professor of Law at Auckland from 1939 to 1942. He was said to be "by far the most high-powered lawyer to teach in Auckland until that time, or for many years to come”. See J Northey, "Professor Julius Stone" Cooke supra note 5, at 196-7. He was succeeded by AG Davis (LLB Auckland and LLD London), who had lectured in England and Wales and published The Law Relating to Commercial Letters of Credit (1939) (id, 197-9). Davis was Professor of Law at Auckland 1942-64.

5 Per CC Aikman, Cooke supra note 5, at 200. McGechan was born and graduated BA LLB in Sydney, was called to the bar in New South Wales in 1930, and was Professor of Law at Victoria 1942-54: see (1954) 30 NZLJ 71. Beaglehole wrote that McGechan was "learned, accurate and intelligible" and that "though an Australian might have been deemed by Stout ipso facto incapable of Roman law, at least his name shared in the great inheritance": see Beaglehole, supra note 46, at 246.

I Campbell, "In Memoriam Robert Orr McGechan” (1955) 1 Victoria University Law Rev 9 at 13.

McGechan explained that the case method was to be contrasted with the traditional lecturing method, involving the oral transmission of the law in class (often backed up by textbooks). The case method involved the prior presentation of written materials, including leading cases, to students, the focussed reading of these materials before class, and the critical and contextual discussion in class of what the law was and how it had evolved: see RO McGechan, "The Case Method of Teaching Law" (1953) 1 Victoria University Law Rev 9 at 11 \& 14-15. McGechan stated that "the primary purpose of the Review is educational in the sense that its aim is to develop the capacity of students to expound the law clearly in print”: see (1953) 1 Victoria University Law Rev 3.

Id 12-16. See also R 0 McGechan, "The Profession and the Teaching of the Law" (1947) 23 NZLJ 110 and RO McGechan, "Law Teaching Overseas" (1951) 27 NZLJ 361.

Cooke claimed that, in the period 1946-51, "Victoria possessed, in Williams, 
McGechan, Campbell and Braybrooke, a law teaching staff, substantially fulltime, whose strength may have been unsurpassed anywhere in the Englishspeaking world": see Cooke, supra note 73, at 187. Thomas Eichelbaum, who was at Victoria from 1949 to 1954, said that "in those days Victoria was certainly regarded as the leading law faculty in the country: see [1989] NZLJ 48. But see now JL Caldwell, "Graduate employment survey" [1990] NZLJ 162 at 163.

Parton, supra note 21, at 72.

81 Two other remarkable objections were raised. It was said that "at Canterbury and Otago all the teaching is done by practitioners in active practice. They would be put in the invidious position of having to mark the script of and to give or withhold a recommendation for a pass to sons of (perhaps valued) clients and of fellow-practitioners". Further, it was said that in these colleges "appointments of lecturers are made from year to year and reappointment depends to some extent upon the degree of success which has attended such lecturer's students in the examinations. It will be embarrassing to lecturers to have substantially the control of passes and failures”: Parton, supra note 21, at 73.

Id.

83 Cullen, supra note 4, at 134-5. Cullen states that the arguments for the retention of Latin "had always been weak - the Latin terms in legal usage in New Zealand are relatively few, require no knowledge of the language as a whole, and are conventionally and abysmally mispronounced by the legal fraternity in any case".

85 Universities Act 1961.

86 Cullen, supra note 4, at 135.

87 Law Practitioners Amendment Act 1961 and Parton, supra note 21, at 141-2. Parton notes that the independent development of each of the law schools meant that the concept of one special school of law became irrelevant.

Cullen, supra note 4, at 136. At Otago, the proportion of female graduates rose from 5\% in 1971-3 to 28\% in 1979-81: see J Smillie, "Results of a Survey of Otago Law Graduates 1971-1981" (1983) 5 Otago Law Review 442). At Canterbury, in 1955 law students numbered 97; in 1979 the number had grown to 708 including 203 women: see Matson, supra note 37, at 4.

89 J Northey, “Trends in Legal Education”, [1970] NZLJ 250.

90 Cullen, supra note 4, at 140 and A Haslam, "Some Reflections on Legal Education in New Zealand” (1970) 2 Otago Law Review 116. Smillie’s survey of Otago law graduates found that, whereas $87 \%$ of graduates in 1971-3 had employment arranged when admitted to practice, this declined in 1979-81 to $55 \%$ of graduates: see Smillie, supra note 88 , at 446 . See also P McHugh, "Law Graduate Unemployment" [1979] NZLJ 1. Yet the legal academic world was slow to place restrictions on student numbers in view of "the open door policy of New Zealand tertiary education - the philosophy that every person who is educationally qualified for admission to the university is entitled to a place in the faculty of his choice": see PBA Sim, "The Ormrod Report and Legal Education in New Zealand (1973) 3 Otago Law Review 76 at 86.

91 Id 141. Eichelbaum CJ recalls that he had one year full-time and then started work in 1950 for Chapman Tripp and Co: see [1989] NZLJ 48.

92 Cullen, supra note 4, at 139.

93 At Otago, the percentages of part-time students were: 68.3 (1955-8), 53.1 (1959-62), 24 (1963-6), 19 (1967-70), 14 (1971-4), 12.3 (1975-8): SW Cullen, supra note 4 , at 139 .

94 The Committee noted the long time involved in completing a degree, the high failure and drop-out rates, and the lack of academic commitment characteristic 
of many part-time students: see GW Parkyn, Success and Failure at the University (Wellington: New Zealand Council for Educational Research, 1959) volume I, and Cullen, supra note 4, at 139.

Sinclair, supra note 42, at 256.

At Auckland University the figures were: 1964212 F/T 214 P/T; 1969567 F/T $161 \mathrm{P} / \mathrm{T}$, and $1979589 \mathrm{~F} / \mathrm{T} 235 \mathrm{P} / \mathrm{T}$ (id). At Otago University the figures were: 1962: 67 F/T 62 P/T; 1969: 220 F/T 33 P/T; 1978: 527 F/T 39 P/T: see Cullen, supra note 4, at 139 .

97 Sim, supra note 90 , at 77.

98 In 1992, Professor Grant Hammond stated that "over eighty percent of the persons who graduate in law from Auckland graduate with a degree in another discipline as well as law”: see [1992] NZLJ 195.

99 DP Derham stated in 1955 that "at Canterbury and Otago, the members of the Faculty, being part-time teachers and practitioners, have little time and apparently not much interest in developing the University Law Libraries. They rather naturally take the view that the practitioners' library which is available for students is adequate for their needs": see "Legal Education" (1966) 2 NZULR 130,131.

100 Northey, supra note 89, at 250.

101 Guest served as Otago Law School’s first full-time Dean until his death in 1967. His inaugural lecture in 1961 was entitled "Freedom and Status", and was said to have "indicated his intellectual courage and originality of mind": see A Haslam, supra note 90, at 113. In 1968 an annual memorial lecture in his honour was instituted at Otago Law School. KJ Keith testified to Guest's "road wisdom, his experience, his wit, and his friendship": see (1991) 3 Otago Law Rev 363. See also Cooke, supra note 5, at 201-2.

102 He was Dean at Otago 1968-80. He was described as a "patient, kind and gentle man", who "had a remarkable ability to move quickly to the essence of any legal matter and relate that understanding to others in easily understood terms": see (1989) 7 Otago Law Rev iii.

103 Matson, supra note 37, at 3.

104 Sinclair, supra note 42, at 210. Northey became dean in 1965 and died in office in 1983: see [1984] NZLJ 2. He was a key member of the Public and Administrative Law Reform Committee, which created the Judicature Amendment Act 1972, the foundation of judicial review in New Zealand: see [1992] NZLJ 197. See also the tribute to Northey by Chilwell J ([1984] NZLJ 2).

105 Sinclair, supra note 42, at 315.

106 Auckland Law School now has 33 full-time members of staff (including 4 professors) and 7 part-time members; Victoria has 25 full-time members (including 5 professors) and 3 assistant lecturers; Otago has 24 full-time members (including 3 professors) and 1 assistant lecturer; Canterbury has 21 full-time members (including 3 professors); and Waikato has 20 full-time members (including 2 professors). Massey University Department of Business Law has 8 full-time lecturers (including 1 professor) and 2 assistant lecturers: see University Staff Calendars and New Zealand Law Register 1993.

107 On Quentin-Baxter, see [1984] NZLJ 390-1 and (1985) 16 VUWLR 1. Other prominent Victoria academics included Ian Campbell, Ivor Richardson, George Barton, Geoffrey Palmer, and Donald Mathieson.

108 Derham, supra note 99, at 130. For an outline of published legal research up to 1962, see CN Irvine, “Law Publishing in New Zealand” [1962] NZLJ 73.

109 Northey, supra note 89, at 250, [1983] NZLJ 161, and [1992] NZLJ 194. In 1951 the Auckland Law School had less than 2000 volumes in a room seating ten or twelve students; by 1970 it had over 25000 volumes and seats for over 200 readers; and by 1992 it had around 90000 volumes. Richardson noted that at Victoria in 1963 there were 8000 books and space for 45 readers and that in 
1973 the library had 40000 volumes and seated 180: see "Ormrod Report" (1973) 3 Otago Law Rev 91.

110 Sim, supra note 90, at 87.

111 For the development of the Otago Law Review see (1989) 7 Otago Law Rev i-ii.

112 [1970] NZLJ 455. Cooke J described the Review as "the flagship of the Law School and fulfils a valuable role in New Zealand law in providing a sort of running commentary on the decisions of the Courts": see [1992] NZLJ 197.

113 Eg J Northey (ed), Cheshire and Fifoot on Contract (Wellington: Butterworths, 1961), and P Webb (ed), Bromley on Family Law (NZ edition) (Wellington: Butterworths, 1975). Other authors of note were Professors Hinde, Brookfield, Caldwell and Burrows: see [1984] NZLJ 122.

114 AK Turner, “Changing the Law” (1969) 3 NZULR 404,408.

115 In 1970 the Legal Research Foundation held a conference in Auckland (Legal Research Foundation Legal Education in the Seventies; Proceedings of the Forum on Legal Education (1971)) and in 1973 a symposium was held at Canterbury University: see (1973) 3 Otago Law Rev 76. See also JC Thomas, “A modest programme for the improvement of law teaching” (1978) 9 VUWLR 405 and I Macduff, "Self and peer evaluation: an ambitious proposal for the improvement of law teaching” (1982) 13 VUWLR 121.

116 B Coote, "A Law Teacher looks at his Trade" (1968) 3 NZULR 77 and Report of the Committee on Legal Education, HMSO Cmnd 4595 (1971) (the Ormrod Report) 43. Coote, however, acknowledged that the new approach would be difficult for the existing law teachers in New Zealand, who were products of the old system, with "the same habits of thought, and the same limited experience and training" (id 50). See also W Mansell, "On the Paucity of Causes for Jigs in Legal Study" (1977) Victoria University Law Rev 369, and J Hannan, "Knocking which corners off? - The Study of Law as a Mechanism of Social Integration” (1977) Victoria University Law Rev 379.

117 Richardson, supra note 109, at 93. See J Northey, "Legal Education and the Universities” [1962] NZLJ 23, M Casey Forum on legal education (1971) 28 ("the successful lawyer need know very little law, but what he must develop is [a] mature sense of judgment"), J Marshall, "The Lawyer's responsibility to society" [1975] NZLJ 733, JC Thomas, "A modest programme for the improvement of law teaching” (1978) 9 VUWLR 405, and P De Bres, "The LLB degree course" [1986] NZLJ 344.

118 Mooney, supra note 77, at 70. Judith Potter, who attended Auckland Law School in the early 1960s, recalls that Jack Northey returned from a visit to Canada "with a lot of different ideas about how to teach so the case book method was introduced to Auckland Law School and we were expected to participate rather than sit and absorb which had been the traditional style": see [1991] NZLJ 151.

119 KJ Keith, "The impact of American ideas on New Zealand's educational policy, practice and theory: the case of law" (1988) 18 VUWLR 327 at 340.

120 Sim, supra note 90, at 81-3, and Richardson supra note 109, at 92-3 and 94.

121 N Gold, Report on the Reform of Professional Legal Training in New Zealand (Wellington: New Zealand Law Society, 1987) 17.

122 The required courses are: Legal System, Public Law, Contract, Criminal Law, Torts, Land Law and Equity.

123 R Ludbrook, “The Law and the Polynesian” [1975] NZLJ 420, 421. From 1970, the New Zealand Law Society annually awarded a scholarship to the most promising Maori student studying law at a New Zealand university: see [1984] NZLJ 103.

124 Gold, supra note 121, at 25.

125 I Richardson, "Educating lawyers for the 21st century" [1989] NZLJ 86 at 89.

126 M Wilson, “Waikato Law School: A new beginning” (1990) 14 NZULR 103. 
Waikato University itself had been founded in 1964.

127 This means "The horizon where the earth meets the sky/The meeting place of ideas and ideals": see id 106.

128 Id 110-1.

129 The President of the Association of American Law Schools, quoted by G Hammond, "Some Proposals with respect to Legal Education in New Zealand" (1980) 9 NZULR 28,29. See also [1992] NZLJ 195.

130 Coote, supra note 116, at 38. Coote also pointed out that, in the United States and civil law systems, the law teacher had a very high status and influence, as in these jurisdictions the legal system gave a place to the evaluation of legal doctrines (id 48-9). North P recalled the post World War I period when to take an LLM would "brand you at once": see [1971] NZLJ 256.

131 BD Inglis, “Trends in legal education” [1976] NZLJ 39, and Richardson, supra note 109, at 92. Richardson proposed that staff should spend refresher leave periods in law offices or in government or business in New Zealand as an alternative to the traditional overseas leave.

132 WL Twining, "Goodbye to Lewis Eliot; The Academic Lawyer as Scholar" (1980) 15 Journal of the Society of Public Teachers of Law 2 at 25. Twining suggested that a major reason for this is that much legal endeavour has gone into broad surveys of large fields "rather than into detailed, critical monographic topics on specific topics” (id).

133 [1992] NZLJ 195.

134 A Legal Research Foundation questionnaire of 400 Auckland practitioners found that $73 \%$ said legal education should be more oriented to practical problems encountered in practice, and 93\% said there was a need for continuing legal education for lawyers: see [1970] NZLJ 80.

135 [1971] NZLJ 257. North J advised the new barristers assembled before him that, while both theoretical and practical knowledge were valuable and useful, success at the bar would depend more on good judgment and thorough acquaintance with the facts of cases than knowledge of the theory of the law. WG Smith, President of the New Zealand Law Society, complained in 1974 that "the education of lawyers is becoming increasingly irrelevant in providing those skills that the public is entitled to expect from its lawyers". While accepting that "the strains and pressures of practice are such that it is more essential than ever that the lawyer's education is broadly based”, he called for a College of Law to provide practical instruction: see [1974] NZLJ 249, 250.

136 Sim, supra note 90, at 85.

137 Per P Clapshaw [1988] NZLJ 120.

138 Earlier, Haslam J had quoted Sir Owen Dixon (Chief Justice of Australia) as noting the knowledge "of a speculative kind which forms a lasting foundation for the support of the daily discipline of practice", which it was proper for the university to teach, and "how to apply it as an art [which] should be surely the work of the profession to teach": see Haslam, supra note 90, at 115.

139 P Temm, “Legal Education in the Seventies” [1970] NZLJ 346. Since 1964 the Auckland District Law Society had conducted continuing legal education lectures at night four or five times a year; and from 1971 it had conducted weekend courses.

140 By the end of 1980 a successful pilot scheme had been conducted in Wellington and there was the promise of consultation in each law school centre to avoid overlap between the Society's programme and university professional education: see DF Dugdale, "Post Admission Practical Training” [1980] NZLJ 521-2.

141 I Muir, “The Law Society’s Skills Training Course — another view” [1981] NZLJ 291-3.

142 Smillie's survey of Otago law graduates 1971-81 found that over $80 \%$ of 
graduates found their law training not helpful in developing knowledge of business practices and the resources of government departments and community service organisations: see Smillie, supra note 88, at 452. See also G Nash “Skills Course or Clinic?” 54 Australian Law Journal 539, I Muir, “Clinical Training for Law Students" [1977] NZLJ 425 (reflecting a call for the Montessori method of "learning by doing"), E Williams, "Practical Training of Lawyers" [1977] NZLJ 391 (reflecting a call for satisfactory "on-the-job" training), and G Hammond, "Legal Education in New Zealand" (1980) 9 NZULR 28 at 35-42 (arguing for the teaching of legal ethics or professional responsibility, practical subjects such as evidence and civil procedure, and trial advocacy).

143 Sim, supra note 90, at 84-5.

144 [1982] NZLJ 280.

145 Gold, supra note 121, at 4 and 7.

146 See DC Lewis, "Observations from an outsider" (1988) 3 Canterbury Law Rev 347.

147 R Moss, "Developments in the Professional Legal Studies Course - The implementation of the Roper Report" [1991] Law Talk 340,7-8.

148 See D Bates, “The Perils of the Small Law School” (1983) 5 Otago Law Rev 458.

149 R Cramton, “Ordinary Religion of the Classroom” (1978) 29 J Legal Educ 247 at 262-3.

150 Gold, supra note 121, at 17. 